\title{
Clean Water Supply Development Model in Sentul City
}

\author{
${ }^{1}$ ASEP SUHERI, ${ }^{2}$ C. KUSMANA, ${ }^{3}$ MYJ. PURWANTO, ${ }^{4}$ Y. SETIAWAN \\ ${ }^{1}$ School of Life Sciences and Technology, Bandung Institute of Technology, Indonesia. \\ ${ }^{2}$ Department of Forest Ecology, Faculty of Forestry, IPB University, Indonesia. \\ ${ }^{3}$ Department of Civil and Environmental Engineering, IPB University, Indonesia. \\ ${ }^{4}$ Center for Environmental Studies, IPB University, Indonesia. \\ Correspondence author: asep@sith.itb.ac.id
}

\begin{abstract}
This study aims to predict the current and future demand for clean water, and efforts to develop clean water supply from a social aspect in Sentul City (SC). To estimate the need for clean water, it is predicted from the total population from year to year. Forecasting population in this study uses arithmetic and geometric methods, while Stella software is used to facilitate the analysis. Starting in 2030, it is estimated that SC will experience water shortages. The Community Based Drinking Water Supply and Sanitation or PAMSIMAS program and installation of smart tanks are proposed to overcome the problem water shortage of rural residents in SC. Meanwhile, for urban residents, they can collect rainwater that falls on the roofs of houses and collect it in smart tanks. The implementation of PAMSIMAS program and the installation of smart tanks in SC has an important function as a supplier of backup raw water sources to overcome current and future shortages of clean water.
\end{abstract}

Keywords: Clean water demand and supply, Arithmetic and geometric method, Social aspects.

\section{Introduction}

The need for clean water generally increases every year. On the contrary, the supply of clean water is limited because of decreasing reservoir areas, constructions which do not consider the balance of nature, and raw water resource exploitations which do not consider the sustainability of water resources. For anticipating water crises, it is crucial to maintain the sustainability of existing water resources, apply the efficiency in water-use, and search for new water resource alternatives (Loucks and Beek, 2017; Cosgrove and Loucks, 2015; Jiménez and Asano, 2008; FAO, 1976). Economic and social development is very dependent on the availability of water, including the fulfillment of basic human needs (Fang, 2020; Hall et al., 2014).

The Sentul City (SC) area often experiences water supply problems. Clean water supply for SC areas originating from PDAM Tirta Kahuripan Bogor Regency is often constrained due to small water discharges, as well as technical problems for the distribution of clean water. Besides, PDAM services for the Bogor Regency region only reached $41.7 \%$ of the total that had to be served (BDDPA, 2014). In addition to utilizing PAM water, some residents in SC also get water by making dug wells.

Rivers that flow in SC area are the Citeureup River and the Cikeas River. Rainwater flows from the east and south with higher elevations to the western and northern parts of the region with lower elevations. SC area is ground water-scarce area. Groundwater has little potential and is influenced by seasons; it is present in the form of free groundwater in the rock section and a soil depth of $12 \mathrm{~m}$. Springs in SC are found in river valleys and have generally very small water discharges (Sentul City, 2012).

The availability of water in SC is very limited both in terms of quality and quantity, so that if you only rely on the current water availability without additional water supply, then in the future SC will experience a

Received: 2019-09-13, Revised: 2020-01-22, Accepted: 2020-12-16

Print ISSN: 0215-8175; Online ISSN: 2303-2499. DOI: https://doi.org/10.29313/mimbar.v36i2.5116

Accredited Sinta 2 based on the decree No.10/E/KPT/2019 until 2024. Indexed by DOAJ, Sinta, Garuda, Crossreff, Dimensions 
shortage (deficit) of clean water. Thus, the developer and the community must work as early as possible to find a solution to obtain an additional water supply. In terms of social aspects, several ways can be done for the independence of water supply to increase water supply in SC including through the Community Based Drinking Water Supply and Sanitation or PAMSIMAS program that utilizes Citeureup and Cikeas rivers and harvests rainwater falls on the roofs of each house and stores it in a container namely Tangki Pintar (Smart Tank).

Drinking water is a basic need crucial for human life in a sustainable manner to improve public health (Daley et al., 2015). A National Policy and Strategy for the Development of Drinking Water Supply Systems is stipulated by a Minister of Public Works Regulation. It also needs to be equipped with Technical Guidelines and Guidelines for the Implementation of SPAM Development (RMPWHRI, 2016). To meet the needs of clean water, residents in SC are supplied from PDAM Tirta Kahuripan, Bogor Regency. The distance from PDAM water reservoir to the residential $\mathrm{SC}$ location is relatively far around $15 \mathrm{~km}$ with a height difference of about $10 \mathrm{~m}$.

The PDAM is the agency assigned and responsible for providing clean water to the community through the SPAM (Drinking Water Supply System) program which deals with the process of supplying drinking water starting from the planning of raw water sources (quality \& quantity), transmission of raw water from intakes (raw water sources) to water treatment plants (IPA), Water Treatment Installation/IPA technologies that are effective in terms of performance (GR, 2005; GRRI, 2015).

$\mathrm{SC}$ is an independent city in Bogor Regency, developed by PT. Sentul City Tbk, which developing its area committed to the principle of green development through a response to the city parameters. The concept of eco-city is applied to landscapes and buildings. This area was developed as a residential, commercial, office, industrial, tourism, and special (commercial) area.

There are two different characteristics in the population growth in SC, namely the characteristics of the group of residents who have lived long in the village with a natural population growth of $3.03 \%$ (SCA, 2017; SCA, 2016), and the group of newcomers who inhabit housing in urban areas with an estimated annual population of 4,960 people
(PT. Sukapura Graha Cemerlang 2017 and Masterplan Sentul City 2011). Another characteristic is the water demand where urban residents consume more clean water compared to villagers with a ratio of $2: 1$. The urban population's water needs are 120 liter/day/capita or $43.8 \mathrm{~m}^{3} /$ capita/year; and the rural population's water needs are 60 liter/day/capita or $21.9 \mathrm{~m}^{3} /$ capita/year (Indonesian National Standards Agency or BSNI, 2002).

The clean water supply for urban SC residents comes from PDAM Tirta Kahuripan, which often constrained by water shortages, among others due to the malfunction of water towing machine because the water reservoir belongs to the PDAM in Kandang Roda and the reservoir belongs to SC management is 20 meters different, causing the water supply to be choked. One solution is to implement smart tanks and socialization to the community for the construction of smart tanks in individual houses/buildings in urban areas. Meanwhile, overcoming water shortage of rural residents in SC is carried out by utilizing the water of Cikeas and Citeureup River through the PAMSIMAS program (Putri, 2016; DGCK, 2011).

For the development of dynamic urban $\mathrm{SC}$ areas, it is deemed necessary to know the predictions and dynamics of water demand over time, the material needs of planning, and analysis relating to populations. Therefore, it is necessary to predict the need for clean water based on the population in urban SC now and in the future, and what programs can be proposed following the socio-economic conditions of the local community to increase water supply. Hence, research is necessary to predict the need for clean water today and thirty years to come and efforts to develop raw water supply in terms of social aspects of society and biophysical conditions in SC. Distinguished social aspects of the village environment are residents who live in rural areas in SC, and the urban environment is residents who live in urban areas, mostly as outsiders (Schootman et al., 2016).

To make it easier to design, formulate, calculate, analyze data, and present the results of prediction, analysis of clean water needs based on the number of residents in SC assisted by using Stella 9.0.1 software (Richmond, 1995). This software has been tested well because if there are errors in the formulation there will be an error in the validation test. 


\section{Research Methodology}

Forecasting population in rural SC in this research uses the geometric method as recommended in the 2001 booklet (DGWR, 2001); while the arithmetic method is used for forecasting the number of residents in urban areas. To simplify population projections, predict clean water needs, and draw graphs of the relationship between population dynamics and clean water needs, and analyze results, Stella 9.0.1 software is used (Stella, 2013).

The arithmetic method is based on the assumption that the rate of population change is constant, using the assumption that population growth is the same every year. The arithmetic model graph for urban residents in SC can be seen in figure 1 (McGhee, 1991) below.

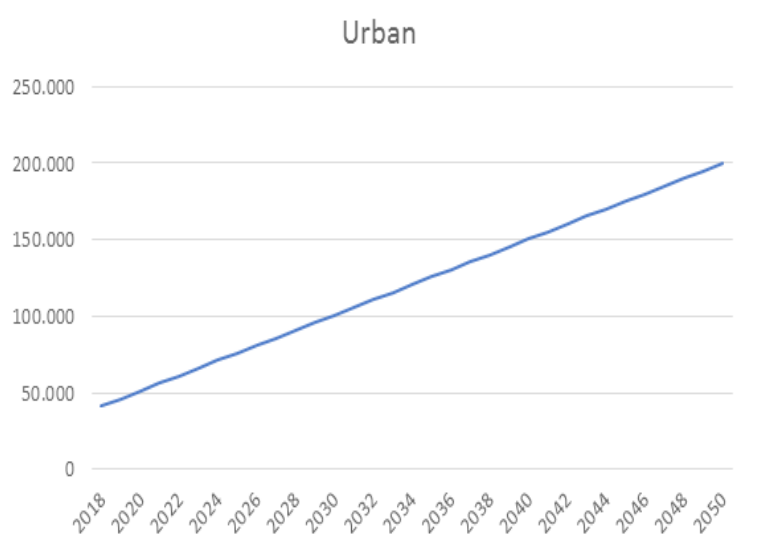

Figure 1. The Arithmetic Model of Urban Population Growth in SC

The geometric method assumes population growth using basic compound interest. The population growth rate is assumed to be the same every year (Marlis and Arbi, 2019). A graph of the geometric model of rural populations in SC can be seen in figure 2.

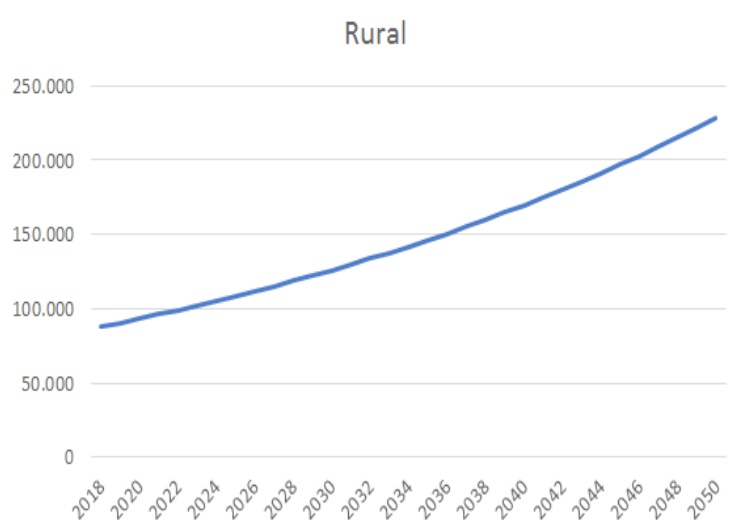

Figure 2. Geometric Model of Rural Population Growth in SC

\section{Water Need Prediction}

To predict the water need in a certain area, the study used an equation which was a multiplication between the inhabitant number and the standard of water need. The following equation is a general equation for calculation:

$Q y=d y \times P y$

where:

Qy : The water need ( $\left.\mathrm{m}^{3} / \mathrm{second}\right)$

$d y$ : The standard of need

$P y$ : The user number

The eligibility standard for clean water needs is 49.5 liter/capita/day. For the needs of the human body, the water needed is $\mathbf{2 . 5}$ liter per day. Standard water requirements in humans usually follow the formula of $30 \mathrm{cc}$ per kilogram of body weight per day. That is if someone weighs $60 \mathrm{~kg}$, then the daily water needs of $1,800 \mathrm{cc}$ or 1.8 liter. The UNESCO world body itself in 2002 has established a basic human right to water that is equal to 60 liter/person/day. The Directorate General of Human Settlements of the Ministry of Public Works subdivide the drinking water standards based on the location of the region as follows (DGWR, 2001): (a) rural area with the need at value of 60 liters/capita/day; (b) small city with the need at value of 90 liters/capita/ day; (c) medium city with the need at value of 110 liters/capita/day; (d) large city with the need at value of 130 liters/capita/day; (e) Metropolitan city with the need at value of 150 liters/capita/day.

Based on the Minister of Home Affairs Regulation No. 23 of 2006 concerning Technical Guidelines and Procedures for Regulating Drinking Water Tariffs in Regional Drinking Water Companies CHAPTER I General Provisions Article 1 paragraph 8, it states that the Standard for Basic Water Supply Needs is a water requirement of 10 cubic meters/family head/month or 60 liters/person/ day, or as much as other volume units stipulated further by the Minister conducting government affairs in the field of water resources (HAMR, 2006). Clean water network installation must be technically optimal, safe for applicator safety, safe for pipelines and must comply with SNI 8153: 2015 concerning pipe systems in buildings.

\section{Stella 9.0.1 Software}

To facilitate the analysis of data, this research applies Stella software. Stella is a visual programming language software that uses the principle of dynamic models 
with object-oriented. This program was first designed \& introduced by Barry Richmond in 1985 and was developed by ISEE Systems. Stella has been used in academia as a teaching tool and has also been used in a variety of research and business applications (Oktavariani and Sofyan, 2015; MinjarezSosa, 2014; Saltera, 2013; Naimi and Voinov, 2012; Richmond, 1985).

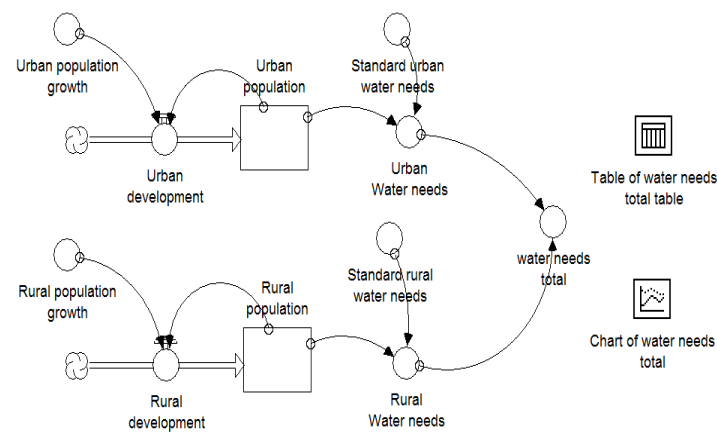

Figure 3. Structure of the water emand prediction model in SC

To analyze the prediction model for clean water needs based on a population over time, Stella 9.0.1 software is used with the structure of the model as can be seen in figure 3 (Shiflet and Shiflet, 2014). Stella application is software for flow-chart based modeling. Stella is an interpreted programming language with a multi-level hierarchical environment approach, both for constructing models and interacting with models. Besides being familiar in its use, the Stella application has various capabilities to assess various possibilities (scenarios) in finding the best alternative for clean water supply.

\section{Results and Discussion}

\section{Geographical Location and Govern- mental Administration}

Geographically, SC is located in the coordinate of $06^{\circ} 33^{\prime} 55^{\prime \prime}-06^{\circ} 37^{\prime} 45^{\prime \prime}$ LS and $106^{\circ} 50^{\prime} 20^{\prime \prime}-106^{\circ} 57^{\prime} 10^{\prime \prime}$ BT. The area of SC which stated in the SC Masterplan was 2,465 ha located in the border area at value of 3,001.4 ha. Otherwise, this study conducted a spatial analysis at value of 2,905.33 ha which was appropriate with the borderline area in the vector form, as required from city planner side. Based on governmental administration, SC is located in 8 Villages and 2 Sub-districts, including Cipambuan Village, Babakan Madang Village, Citaringgul Village, Bojong Koneng Village, Sumur Batu Village, Cijayanti Village, Kadumanggu Village, and
Cadas Ngampar Village. The sub districts are Babakan Madang and Sukaraja, located in Bogor Regency. The border area of SC is as follows:

North : Cipambuan Village and Kadungmanggu Village.

South : Nanggrak Village and Cijayanti Village.

West : Cijayanti Village, Cikeas Village, and Cadas Ngampar Village.

East : Hambalang Village and Karang Tengah Village

\section{Inhabitants}

Generally, the inhabitant settlements in Sukaraja, Babakan Madang, and Citeureup Sub-district are divided into two categories, including the settlements which growth are planned and unplanned. The settlements which growth was planned in two to three latest decades, were built in the middle and large scale for middle and up-middle income societies. Meanwhile, the settlements which growth was unplanned, had the kampong/ village pattern, located in the area of SC and around. The condition of inhabitant in every village is shown in Table 1.

\section{Water Need Analysis}

Primary data collection is carried out through questionnaires to institutions and communities domiciled in SC. Data needed includes population, population growth, and others. Agencies related to this research include Bogor Regency Central Bureau of Statistics, Regional Planning and Development Agency (Bappeda), Public Works and Public Housing Agency (PUPR), and others.

In 2017, the number of rural area inhabitant in SC was approximately 88,005 persons. According to the formulation of inhabitant growth rate, the researcher conducted a calculation of rural area inhabitants who stayed in the area of SC. The result of the calculation shows the rural area inhabitant growth rate in SC is at a value of $3.03 \%$. Based on the growth rate, it is estimated that the rural area inhabitant in 2025 and 2050, respectively is 108,528 persons and 229,452 persons.

The inhabitant of SC has reached approximately 41,300 persons. These city inhabitants are newcomers from the outside area. They purchased the settlements in SC, not inhabitants who were born and grew up in SC such as rural area inhabitants in SC. It has an inhabitant target at value of 40,000 heads of family (KK). Therefore, the inhabitant target is 200,000 persons by assuming every 
Table 1

The condition of inhabitant in Every Village in 2017

\begin{tabular}{lllll}
\hline No. & \multicolumn{1}{c}{ Sub-district/Name of Village } & Area $\mathbf{( m}^{\mathbf{2}} \mathbf{)}$ & Village area (ha) & Number (person) \\
\hline & Babakan Madang Sub-district & & & \\
1. & Cipambuan & 92.46 & 201 & 573 \\
2. & Babakan Madang & 274.62 & 233 & 12719 \\
3. & Citaringgul & 275.14 & 345 & 10505 \\
4. & Bojong Koneng & 1057.49 & 2441 & 14268 \\
5. & Sumur Batu & 519.49 & 484 & 9474 \\
6. & Cijayanti & 624.53 & 2551 & 18536 \\
7. & Kadumanggu & 5.23 & 410 & 18563 \\
\hline & Sukaraja Sub-district & & \\
8 & Cadas Ngampar & 53.83 & 183 & 8238 \\
\hline & TOTAL & 2905.33 & 6848 & 97876 \\
\hline
\end{tabular}

head of a family consists of 5 members. It targets the accomplishment of the first level establishment at an area approximately $50 \%$ of the total area in 2025 . Therefore, it is assumed the ultimate establishment will be accomplished in 2050 and the urban area inhabitants who have been staying in SC by additional settlements is at value of 992 unit per year or 4,960 persons per year.

This study uses Software Stella 9.0.1. By inputting the rural area inhabitant number data and the inhabitant growth rate, it results in the rural area inhabitant number per year and the graphic of inhabitant growth. The increase of rural and urban area inhabitant and the water need in SC in $2018-2050$ is shown in Figure 4.

The projection results show that estimation of the number of inhabitants is 76,020 and 108, 529 for the urban and rural areas respectively with total 184,549 persons in 2025 . By those inhabitant numbers, it is necessary to conduct a projection to domestic and non-domestic water need. The water need projection in SC is calculated by assuming the water consumption is at value of 120 liters/day and 60 liters/day for urban and rural area inhabitants, respectively. The total of inhabitant water needs in the area of SC in 2025 is projected to reach 5,706,462 $\mathrm{m}^{3} /$ year and $13,785,875 \mathrm{~m}^{3} /$ year in 2025 and 2050, respectively. Since 2037, water needs are $9,334,985$ and water availability is currently $9,268,080 \mathrm{~m}^{3} /$ year, resulting in a water deficit of $66,905 \mathrm{~m}^{3} /$ year and in 20150 of 4,502,268 $\mathrm{m}^{3} /$ year.

The equation of water demand prediction in SC analyzed by Stella 9.0.1's open-source software is presented in figure 5 .

\section{Water Supply}

Clean water in SC is supplied from Tirta Kahuripan PDAM with a discharge of 17,280 $\mathrm{m}^{3} /$ day, from a Water Treatment Plant (WTP) of $6,912 \mathrm{~m}^{3} /$ day, and the Sewage Treatment Plant (STP) of $1,200 \mathrm{~m}^{3} /$ day (SGC, 2017). Based on the current sources, the SC can supply $25,394 \mathrm{~m}^{3} /$ day or $9,268,080 \mathrm{~m}^{3} /$ year (SGC, 2017). It is predicted that in the future, the water demand in the SC will continue to increase and if it is assumed that the water supply is fixed (ceteris paribus), there will be a water deficit. To overcome this problem, it needs additional supplies to cover the shortfalls that will occur by exploring the potential of raw water sources in SC Cikeas and Citeureup rivers which have potential as raw water sources. As an independent city, the SC should be able to meet water needs taken from water sources in its area. In addition to utilizing river water, another source of water that can be utilized is by directly harvesting rainwater captured by the roofs of residents' houses and collecting it in a smart tank for further processing to become clean water.

\section{Water Balance}

If it is assumed that the availability of water in the future is still as big as what is currently supplied, it will only be sufficient until 2029. In the following years, there will be a shortage of clean water. In 2030, there will be a water shortage (deficit) of 11,938 $\mathrm{m}^{3}$; in 2040, of $3,469,963 \mathrm{~m}^{3}$; and in 2050, of $7,011,102 \mathrm{~m}^{3}$. Projections of the difference between water supply and water demand are presented in Table 2. 
Relationship of population urban, rural, water need, and water balance

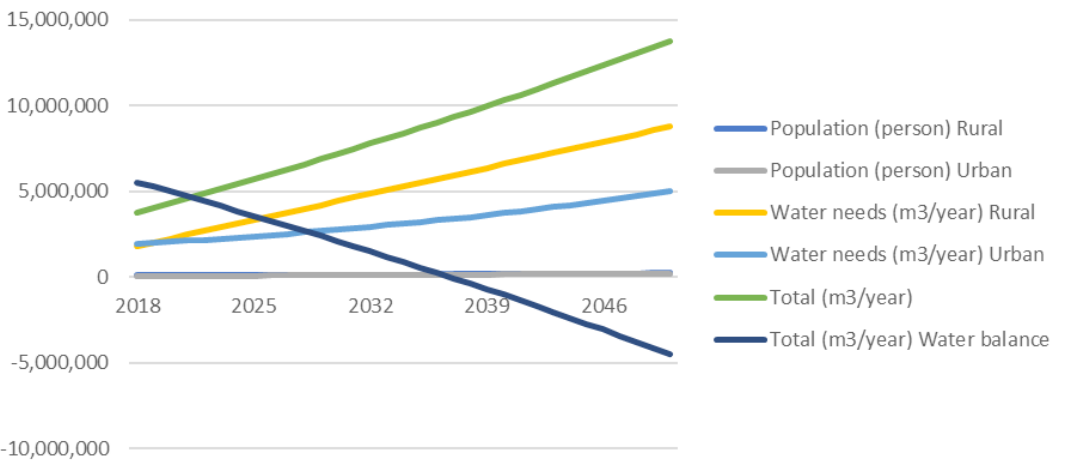

Figure 4. The relationship between the number of rural and urban area inhabitants and water need in SC during 2018 - 2050 by Stella 9.0.1.

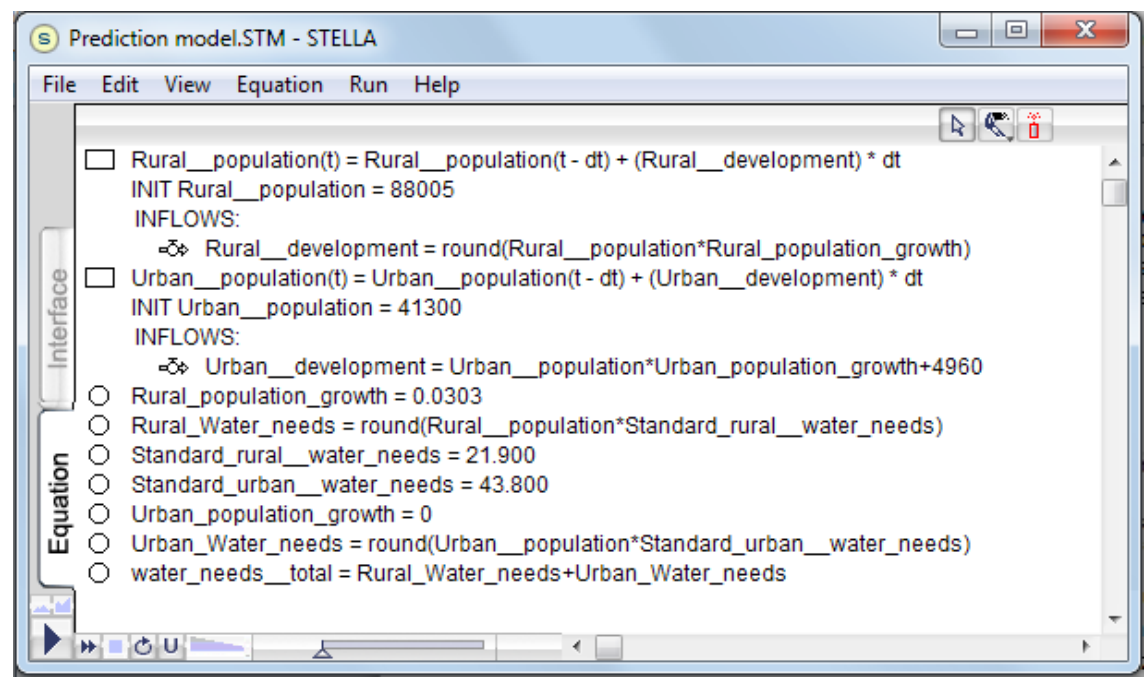

Figure 5. The equation of water demand prediction

\section{Clean Water Development Strategy}

The development of clean water sector in SC is dealing with economic, social and environmental aspects. In the economic aspect, clean water sector is required to adjust to economic rules to guide the allocation of water resources and encourage the implementation in business sector such as a professional corporate, have efficient behavior, and produce benefits for other economic sectors. In social aspect, water sector is dealing with social values that must be aspirated in development and its position as the most basic public sector (Ameyaw et al., 2017; Judith, 2009; Idelovitch and Ringskog, 1995). Whereas, in an environmental aspect, clean water sector is dealing with social nuanced implications and influences the allocation of water resources. The synergy between environmental and social aspects can determine the behaviour of water resources management and the demand for clean water. Overall, the clean water sector policy is in line with achieving the highest benefits from the development and conservation of water resources, among others (UN, 1979): (1) increasing regional or national income, (2) redistributing income among regions, (3) redistributing income among various community groups, (4) improve the state of public health, and (5) improve environmental quality.

The water supply policy approach can be separated into two: social (worst first) and economic (growth point)(Khan et al., 2020). A social or non-economic approach focuses on water supply in areas that are naturally short of water due to climate influences or disruptions (Walker et al., 2015; Nugroho, 2003. The economic approach is focused on areas with high potential for economic development. Provision of water is intended to 
Table 2

Water Supply, Water Demand Projections, and Water Balance in SC

\begin{tabular}{|c|c|c|c|c|}
\hline Item & 2020 & 2030 & 2040 & 2050 \\
\hline Water supply (m³/year) & 9.268 .080 & 9.268 .080 & 9.268 .080 & 9.268 .080 \\
\hline Water demand (m³/year) & 5.893 .749 & 9.280 .018 & 12.738 .043 & 16.279 .182 \\
\hline Difference ( $\mathrm{m}^{3} /$ year) & 3.374 .331 & -11.938 & -3.469 .963 & -7.011 .102 \\
\hline Difference (\%) & 57,25 & 0 & $-27,24$ & $-43,07$ \\
\hline
\end{tabular}

Source: Calculation results, 2019

provoke economic activities towards achieving a high quality of life by applying facilities and modern technology (economic schemes). This approach requires intensive investment to produce water quality that meets health requirements (Muntalif et al., 2017; Anandini, 2011).

The clean water policy framework in Indonesia refers to the development of clean water in urban areas based on investment (World Bank, 1993). The formulation of clean water sector development strategies is specified in social, economic and environmental aspects. It is expected to have a positive impact in each aspect proportionally, sustainably, and bring increased welfare (social benefit). The formulation describes the strategy of managing water resources consisting of two important activities, namely water resources analysis (assessing physical aspects and factors that affect water resources, and defining the strategy); and the process of determining the forms of management of water resources (Apostolaki et al., 2019; Grizzetti et al., 2016; Le Moigne et al., 1994; DMHA, 1999; Al-Layla et al., 1980). Broadly speaking, the formulation of the strategy is presented in Table 3.

\section{PAMSIMAS Program}

One program that involves community participation to overcome problem of the availability of clean water and a decrease in the degree of environmental health of the community due to poor sanitation infrastructure conditions in rural areas in the SC including the Provision of CommunityBased Water Supply and Sanitation Facilities (PAMSIMAS) which is supported by Ministry of Public Works and Ministry of Health. By the demands of new paradigm of people-centered development, the bottom-up planning approach should naturally be enlarged and become the core of the development process that empowers the community (Jiménez et al., 2019; Braimah et al., 2016). The PAMSIMAS program uses a development paradigm that focuses on bottom-up development strategies based on the mobility of human, natural, and institutional resources to meet the basic needs of the community. The approach principles to the implementation of the PAMSIMAS program are as follows: community-based, partnership, participatory, transparency, responsiveness, appreciation, and development, the sustainability of facilities, siding with the poor, gender equality, and being accountable (ADB, 2016).

According to Jennifer and Narayan (1998), participation is a process whereby the parties involved influence and control development initiatives, decisions and resources. Participation has a different side, starting from providing information and consultation methods to mechanisms for collaboration and empowerment that provide opportunities for stakeholders to have more influence and control. Participation is various forms of mass and individual actions that show a reciprocal relationship between the government and its citizens (Pandeya, 2015; Hamisi, 2013). In general, the patterns of citizen participation can be divided into four types: (1) participation in elections (electoral participation); (2) group participation; (3) contact between citizens and the government; and (4) direct citizen participation. Community participation can be interpreted as community empowerment, participation in planning activities, implementation of development programs/projects, and actualization and willingness of people to sacrifice and contribute to the implementation of development programs (Adisasmita in Cahyaningrum 2017; Das, 2015). In the development process, participation functions as input and output. As an input, community participation functions to grow the community's ability to develop independently. As output, participation can be moved or built. Here participation serves as an output of the process of stimulation or motivation through various efforts (Purwanti et al., 2019; Yusri, Y. 2019).

The PAMSIMAS program is one of the government's programs to increase access for the number of rural poor people to better 
Table 3

Strategies, Targets and Operational Steps in Clean Water Sector Development in SC

\begin{tabular}{|c|c|c|}
\hline Strategy & Target & Operational Steps \\
\hline \multicolumn{3}{|c|}{ Social aspects } \\
\hline \multirow[t]{2}{*}{$\begin{array}{l}\text { Increasing level of } \\
\text { population service }\end{array}$} & $\begin{array}{l}\text { Improved services of up to } 80 \\
\text { percent of the population of } \\
\text { urban areas and } 60 \text { percent of } \\
\text { rural residents }\end{array}$ & $\begin{array}{l}\text { Integrated urban area development; Poverty } \\
\text { alleviation; social safety net programs related } \\
\text { to the clean water sector; development of } \\
\text { residential areas. }\end{array}$ \\
\hline & $\begin{array}{l}\text { Utilization of clean water for } \\
\text { social purposes }\end{array}$ & $\begin{array}{l}\text { Public hydrant construction; Helping areas } \\
\text { experiencing water crises }\end{array}$ \\
\hline \multirow[t]{3}{*}{$\begin{array}{l}\text { Clean water sector } \\
\text { institutional development }\end{array}$} & $\begin{array}{l}\text { Building community } \\
\text { participation in the } \\
\text { development of the clean water } \\
\text { sector }\end{array}$ & $\begin{array}{l}\text { Establish a communication network between } \\
\text { stakeholders in the development of the clean } \\
\text { water sector; analyze clean water consumption } \\
\text { periodically }\end{array}$ \\
\hline & $\begin{array}{l}\text { Developing an efficient and } \\
\text { sustainable water sector } \\
\text { economic institution }\end{array}$ & $\begin{array}{l}\text { Formulate institutional relationships that are } \\
\text { conducive to the development of clean water } \\
\text { sector; integrated management, sharing, or } \\
\text { merger; strengthening the independence and } \\
\text { authority of PT. SGC; formulation of PDAM } \\
\text { performance evaluation standards that consider } \\
\text { environmental aspects; evaluating PDAM } \\
\text { performance }\end{array}$ \\
\hline & $\begin{array}{l}\text { Develop legal institutions in the } \\
\text { clean water sector }\end{array}$ & $\begin{array}{l}\text { Establish reward, punishment and incentive } \\
\text { mechanisms }\end{array}$ \\
\hline
\end{tabular}

\section{Economic aspects}

\begin{tabular}{|c|c|c|}
\hline \multirow[t]{2}{*}{$\begin{array}{l}\text { Improving PDAM } \\
\text { performance }\end{array}$} & Increased PDAM revenue & $\begin{array}{l}\text { Optimal price policy; increased water price; price } \\
\text { discrimination between and within consumer } \\
\text { groups }\end{array}$ \\
\hline & $\begin{array}{l}\text { Increased efficiency and profits } \\
\text { of PDAMs }\end{array}$ & $\begin{array}{l}\text { Repair and maintenance of distribution systems; } \\
\text { education and human resource skills in the clean } \\
\text { water sector; improved management and service } \\
\text { quality. }\end{array}$ \\
\hline \multirow[t]{2}{*}{$\begin{array}{l}\text { Increasing share and } \\
\text { regional economic impact }\end{array}$} & $\begin{array}{l}\text { Maintaining the share of clean } \\
\text { water sector above } 0.17 \text { per } \\
\text { cent }\end{array}$ & $\begin{array}{l}\text { Increased growth in demand for clean water; } \\
\text { increased investment }\end{array}$ \\
\hline & $\begin{array}{l}\text { Increased regional economic } \\
\text { activities related to the clean } \\
\text { water sector }\end{array}$ & $\begin{array}{l}\text { Increasing backward economic activity; } \\
\text { increasing future economic activity; construction } \\
\text { of public telephone infrastructure; development } \\
\text { in the field of law and land; economic } \\
\text { development of infrastructure sector/service } \\
\text { sector }\end{array}$ \\
\hline \multicolumn{3}{|l|}{ Environmental aspects } \\
\hline \multirow[t]{2}{*}{$\begin{array}{l}\text { Increasing the quantity } \\
\text { and quality of clean water }\end{array}$} & $\begin{array}{l}\text { Development of raw water } \\
\text { sources }\end{array}$ & $\begin{array}{l}\text { Investment in developing raw water sources; raw } \\
\text { water exploration }\end{array}$ \\
\hline & $\begin{array}{l}\text { Maintenance of raw water } \\
\text { quality }\end{array}$ & $\begin{array}{l}\text { Evaluate the quality of raw and clean water; early } \\
\text { water quality monitoring system; application of } \\
\text { raw water treatment technology. }\end{array}$ \\
\hline \multirow[t]{2}{*}{$\begin{array}{l}\text { Increasing the } \\
\text { environmental carrying } \\
\text { capacity of water } \\
\text { resources }\end{array}$} & $\begin{array}{l}\text { Improving the quality of natural } \\
\text { resources and the environment } \\
\text { of water resources }\end{array}$ & $\begin{array}{l}\text { Analysis of the potential and harvest of water } \\
\text { resources; conservation of forest, land and water } \\
\text { resources; application of environmental quality } \\
\text { standards }\end{array}$ \\
\hline & Control of raw water allocation & $\begin{array}{l}\text { Development and environmental counseling; } \\
\text { strengthen the mechanism of supervision and } \\
\text { application of the law. }\end{array}$ \\
\hline
\end{tabular}

Source: Le Moigne et al., 1994 adapted.

services of clean water and sanitation and facilities, and to improve the value and behaviour of clean and healthy living using a community participation approach. The
PAMSIMAS III program, which is carried out in 2016-2020 as a continuation of the Pamsimas I and II Programs (2008-2015), is an instrument for implementing two national 
agendas that aim to increase population coverage for proper and sustainable water and sanitation services.

Community participation through the PAMSIMAS Program in improving health and cleanliness of the village environment is important and the main thing is the success of the program. Community empowerment is carried out in rural areas by placing assistants/facilitators in each village to implement PAMSIMAS Program for one year starting from planning, implementation, and maintenance stages to program sustainability (Asminar, 2019; Yefni and Haris, 2019; Putri, 2016; Chaerunnissa, 2014).

The PAMSIMAS program is one of the solutions and concrete actions of the government (central and regional), by the support of World Bank, to improve the supply of drinking water, sanitation, and improve the degree of public health, especially in reducing the number of diarrheal diseases and other waterborne diseases. The purpose of PAMSIMAS Program is to create a community that has a clean and healthy life by increasing access for rural and suburban poor to water and sanitation services. Targets of the program are the community, especially rural and suburban poor who have a high prevalence of water-related diseases and do not yet have access to drinking water and sanitation services, have access to drinking water and sanitation services and build a culture of clean and healthy living (DGCK, 2011a; DGCK, 2011b).

\section{SC Masterplan}

Land use plans in the SC area are contained in the SC master plan (Masterplan Sentul City, 2011). The area planned as developed land is 2,420 ha or $83.62 \%$. The development plan for 2015-2025 is divided into five zones with a total development area of 335.6 ha, consisting of an effective building area of $50 \%$, and roads and green space by $50 \%$. PT. Sentul City Tbk (BKSL) is currently developing a Centerra superblock in Central Business District (CBD) of Sentul City with an area of 7.8 hectares. Within the CBD area, there will be Aeon Mall, Vedura Apartments, Saffron Noble Residence, Opus Park Towers, office buildings, and condotels. This area is expected to operate in early 2020.

\section{Spatial Planning Policy}

Based on the Law Number 26 of 2007 concerning Spatial Planning, where the definition of spatial planning includes spatial planning, spatial use and control of spatial use. With the number of urban and rural population in the SC Area which continues to increase from time to time, it will have implications for increasing pressure on the use of space such as the construction of infrastructure and facilities in big cities and metropolitan areas, so that the spatial planning of urban areas needs special attention and give greater attention to protecting the environment. Because water and air pollution are increasing with the increased volumes of domestic and solid waste as well as traffic jams, environmental protection measures are needed, for example by encouraging the application of zoning regulations, applying incentive and disincentive mechanisms, smart growth or growth management principles, etc.

If national development planning is spatial and non-spatial, then spatial planning emphasizes more on the spatial aspects that include structural planning and spatial use patterns, which include the use of land, water, air, and another natural resource (RRI, 2007). The products produced from the spatial planning effort/process are the Spatial Planning in SC implemented in the form of SC Master Plan (2011).

Environmental preservation, which is a concern of spatial planning, aims to systematically encourage public awareness of the environment, for example by implementing 3R (reduction-reuse-recycling) of solid waste and proper environmental management is needed to create a cycle-oriented society in urban areas and the countryside. In this case, the participatory approach becomes one of the chosen approaches, as well as for environmental protection.

\section{Conclusions}

The projection results of water demand in the study area from year to year show a significant increase, while the available water supply is very limited. In the next ten years, SC will experience a shortage of clean water, so that efforts are needed to provide backup clean water, one of which through the PAMSIMAS program and installation of smart tanks.

Considering the complex condition of stakeholders in SC, the strategy for developing clean water in SC must be formulated together and integrated with social, economic and environmental aspects. The strategy is expected to produce a positive impact in 
each aspect proportionally, sustainably, and bring increased welfare (social benefit). The development of the clean water sector in SC is concentrated on the development of the Upper Bekasi Watershed, which is to provide raw water for clean water supply in the SC area.

Following the demands of the new paradigm of people-centered development, in the case of water supply, especially for rural residents in SC, by implementing the Community Based Drinking Water Supply and Sanitation Program (PAMSIMAS) with a bottom-up system to utilize Cikeas river water and Citeureup river. Whereas for urban residents in $\mathrm{SC}$, it is proposed to harvest rainwater directly on the roof of their respective houses and accommodate it with a smart tank to be processed into clean water that is ready for consumption.

The implementation of PAMSIMAS program and construction of smart tanks in SC plays an important role as a supplier of raw water reserves to overcome current and future shortages of clean water.

\section{References}

[ADB] Asian Development Bank. (2016). Toward Mainstreaming and Sustaining Community-Driven Development in Indonesia. Published in 2016. Printed in the Philippines. ISBN 978-92-9257-3164 (Print), 978-92-9257-317-1 (e-ISBN) Publication Stock No. RPT167829-2.

Al-Layla, M. Anis., Ahmad, Shamim and Middlebrooks, E.J. (1980). Water Supply Engineering Design, Ann Arbor Science Publishers, Michigan, USA.

Ameyaw EE., Chan APC and Owusu-Manu DG. (2017). A survey of critical success factors for attracting private sector participation in water supply projects in developing countries, Journal of Facilities Management, 10.1108/JFM-06-2016-0027，15，1，(3561).

Anandini, F. (2011). Identification of Prospects for Sustainability of Community Based Clean Water Supply Activities after the Water and Sanitation for Low-Income Community-2 Program Ends (Case study: Bogor Regency). Journal of Regional and City Planning, Vol 23/2 December 2011.

Apostolaki, S., Koundouri, P., Pittis, N. (2019). Using a systemic approach to address the requirement for Integrated Water Resource Management within the Water
Framework Directive. Science of the Total Environment 679 (2019) 70-79. https:// doi.org/10.1016/j.scitotenv.2019.05.077.

Asminar. (2019). Community Participation and Self-Help in Order to Support Pamsimas III in Bungo Regency, Jambi Province. Journal of Regional and Rural Development Planning Februari 2019,3(1):35-46. DOI: http://dx.doi.org/10.29244/ jp2wd.2019.3.1.35-46.

[BDDPA] Bogor District Development Planning Agency. (2014). Final Strategic Plan Design. Bogor District Development Planning Agency 2013-2018. Bogor. Indonesia.

Braimah, I., Amponsah, O., Asibey, M.O. (2016). The effectiveness of the local management systems of rural water facilities for sustainable service delivery: a case study of the Sekyere East District, Ghana. Sustain. Water Resour. Manag. (2016) 2:405-418. DOI $10.1007 /$ s40899016-0070-7

Cahyaningrum, D. (2017). Community Empowerment Based Local Wisdom In Tourism Of Bajo Community, Wakatobi. International Journal of Scientific \& Technology Research. Volume 6 - Issue 11, November 2017 Edition.

Chaerunnissa, C. (2015). Community Participation in the Community-Based Water Supply and Sanitation Provision Program (PAMSIMAS) in Brebes Regency. POLITICS, Vol. 5, No.2, October 2015.

Cosgrove, W.J., and Loucks, D.P. (2015). Water management: Current and future challenges and research directions. Water Resour. Res., 51, 4823-4839, doi:10.1002/2014WR016869.

Daley, K., Castleden, H., Jamieson, R., Furgal, C., \& Ell, L. (2015). Water systems, sanitation, and public health risks in remote communities: Inuit resident perspectives from the Canadian Arctic. Social Science \& Medicine. Volume 135, June 2015, Pages 124-132.

Das, P. (2015). The urban sanitation conundrum: what can communitymanaged programmes in India unravel? Environment \& Urbanization Vol 27 No 2 October.

[DMHA] Decree of the Minister of Home Affairs No. 47 of 1999 concerning Guidelines for Performance Assessment of Regional Water Supply Companies.

[DGWR] Directorate General of Water Resource. (2001). Guidance of River Area Water Resource. Jakarta. Indonesia.

[DGCK] Directorate General of Cipta Karya, Ministry of Public Works. (2011a). 
PAMSIMAS Guidelines.

[DGCK] Directorate General of Cipta Karya, Ministry of Public Works. (2011b). Community-Based Water Supply and Sanitation Program (PAMSIMAS), Fieldbook Process Analysis and Identification of Problems.

Fang, Y. (2020). The Impact of Innovation Efficiency Factors on the Level of Regional Economic Development. Open Journal of Social Sciences, 8, 343-352. doi: 10.4236/ jss.2020.83031.

[FAO] Food and Agriculture Organization of the United Nations (US). (1976). A Framework for Land Evaluation. FAO Soil Bulletin No. 32. Roma (US): FAO Soil Resources Management and Conservation Service Land and Water Development Division.

[GR] Government Regulation Number.16/2005, concerning the Development of Water Supply System (Drinking Water Supply System, SPAM).

[GRRI] Government Regulation of the Republic of Indonesia Number 122 of 2015 Concerning Water Supply Systems (SPAM).

Grizzetti, B., Lanzanova, D., Liquete, C., Reynaud, A., Cardoso, A.C. (2016). Assessing water ecosystem services for water resource management. Environ. Sci. Pol. 61, 194-203.

Hall, R.P., Koppen, B.V., Houweling, E.V. (2014). The Human Right to Water: The Importance of Domestic and Productive Water Rights. Sci Eng Ethics (2014) 20:849-868. DOI 10.1007/s11948-0139499-3.

Hamisi, F.N. (2013). Community Political Participation in Policy-Making (A Study of Development Planning Deliberations in Jailolo District). Journal of Unsrat.

[HAMR] Home Affairs Minister Regulation No. 23/2006. Technical Guidance and Procedure of Monitoring Drinking Water Tariff in the Drinking Water Regional Company. Jakarta, Indonesia.

Idelovitch, E. and K. Ringskog. (1995). Private Sector Participation in Water Supply and Sanitation in Latin America. Washington, DC: The World Bank.

Jennifer, R.M., and Narayan, D (1998). Participation and Social Assessment: Tools and Techniques, Washington D.C. The International Bank for Reconstruction and Development/The World Bank.

Jiménez, B., Asano, T. (2008). Water Reuse: An International Survey of current practice, issues and needs. IWA Publishing Volume 7. DOI: https://doi. org/10.2166/9781780401881. ISBN electronic: 9781780401881. Publication date: May 2008.

Jiménez, A., LeDeunff, H., Giné, R., Sjödin, J., Cronk, R., Murad, S., Takane, M., and Bartram, J. (2019). The Enabling Environment for Participation in Water and Sanitation: A Conceptual Framework. Water 2019, 11, 308; doi:10.3390/ w11020308.

Judith, A. R. (2009). Regulation and private participation in the water and sanitation sector. First published:09 October 2009 https:// doi.org/10.1111/j.1477-8947.1998. tb00717.x.

Khan, S., Guan, Y., Khan, F., and Khan, Z. (2020). A Comprehensive Index for Measuring Water Security in an Urbanizing World: The Case of Pakistan's Capital. Water 2020, 12, 166; doi:10.3390/ w12010166.

Loucks, D.P., and Beek, E.V. (2017). Water Resources Planning and Management: An Overview. Water Resource Systems Planning and Management, DOI 10.1007/978-3-319-44234-1_1

Marlis, I.S., and Arbi, Y. (2019). Planning for Water Treatment Plant Installation in Tarantang Village, Lubuk Kilangan District, Padang City. Aeration Journal Vol 1 no. March 1, 2019.

Minjarez-Sosa, C.M. (2014). Use of Stella Software for the Modelling of Climate Change Impacts on Water Balance for the Rio Yaqui Basin, Sonora, Mexico. European Scientific Journal May 2014 edition vol.10, No.14.

McGhee., Terence J. 1991. Water Supply and Sewerage. MCGraw-hill, Inc.

Moigne, G. Le., Subramanian, A., Xie, M., Giltner, S. (1994). A Guide to the Formulation of Water Resources Strategy [Technical Paper No. 263]. Washington, DC: World Bank.

Muntalif, B.S., Nastiti, A., Roosmini, D., Sudradjat, A., Sander V. Meijerink \& Antoine J.M. Smits. (2017). Household Water Supply Strategies in Urban Bandung, Indonesia: Findings and Implications for Future Water Access Reporting. Journal of Engineering and Technological Sciences 49(6):811. DOI: $10.5614 / j$.eng.technol. sci.2017.49.6.8.

Naimi, B., Voinov, A. (2012). StellaR: A software to translate Stella models into R open-source environment. Environmental Modelling \& Software 38 (2012) 117-118. doi:10.1016/j.envsoft.2012.05.012.

[NSA] National Standardization Agency (ID). (2002). Indonesian National Standard: the Management of Resource BalancePart 1 Spatial Water Resource [Internet]. [downloaded 2017 August 27 ${ }^{\text {th }}$. Existing 
on 20 Feb 2018 - Standard Nasional Indonesia - Bakosurtanal. http://www. bakosurtanal.go.id/assets/ download /sni/ SNI/SNI\%2019-6728.1-2002.pdf

Nugroho, I. (2003). Clean Water Sector Development Strategy. Jakarta Development Planning MagazineBAPPENAS. 30 (1): 44-58.

Oktavariani, D., and Sofyan, A. (2015). System Dinamics for Optimizing teh Use of Energy in the Domestic Sector at Two Villeges in Bandung Barat Regency. Journal of Environmental Engineering Volume 21 Number 1, May 2015 (pp. 66-76).

Pandeya, G.P. (2015). Does Citizen Participation in Local Government Decision-Making Contribute to Strengthening Local Planning and Accountability Systems? An Empirical Assessment of Stakeholders Perceptions in Nepal. International Public Management Review Vol. 16, Iss. 1, 2015.

Purwanti, A., Wijaningsih, D., Setiawan, F.A. (2019). The Impact of Indonesian Law No. 6/2014 on Women's Political Participation in the Politics of Kelurahan: A Study on Kelurahan's Community Empowerment Institution (LPMK) in Salatiga, Indonesia. Jurnal Dinamika Hukum Vol. 19 Issue 2, Mei 2019. DOI: 10.20884/1.jdh.2019.19.2.2546.

Putri, D.E. (2016). Community Empowerment Through Community-Based Water Supply and Sanitation Programs (PAMSIMAS) (Study in The Village of Ketapanrame, Trawas, Mojokerto District). Journal of Public Administration VOL 4, NO 12 (2016).

[RMPWHRI] Regulation of the Minister of Public Work and Housing of the Republic of Indonesia Number 25 / PRT / M / 2016 about Implementation of the Provision of Drinking Water Supply Systems to Meet Your Own Needs by Business Agencies.

[RRI] Regulations of the Republic Indonesia Number 26 of 2007 about Spatial Planning.

Richmond, B. (1985). A User's Guide to STELLA $®$, High-performance Systems, Inc.

Shiflet, A.B., and Shiflet, G.W. (2014). Introduction to Computational Science: Modeling and Simulation for the Sciences, 2nd Edition. Princeton University Press.

Stella, R.M. (2013). A modern platform for system dynamics, spatial, and agent-based modeling. Procedia Computer Science 18 ( 2013 ) $1784-1793$.

Schootman, M., Nelson, E.J., Werner, K., Shacham, E., Elliott, M., Ratnapradipa, K.,
Lian, M., \& McVay, A. (2016). Emerging technologies to measure neighborhood conditions in public health: implications for interventions and next steps. Int J Health Geogr. 2016 Jun 23; 15(1):20. Epub 2016 Jun 23.

Sentul City (ID). (2011). Masterplan 2.465 Ha Sentul City (Revision). Bogor (ID): PT Sentul City Tbk.

Sentul City (ID). (2012). Sentul City Green Development. Bogor (ID): PT Sentul City Tbk.

Sentul City (ID). (2014). Spatial plan and area of Sentul City 2015-2025. Bogor (ID): PT Sentul City Tbk.

[SCA] Statistical Centre Agency of Bogor Regency (ID). (2016). Bogor Regency in Number (2016). Bogor (ID): Statistical Centre Board of Bogor Regency.

[SCA] Statistical Centre Agency of Bogor Regency (ID). (2017). Babakan Madang Sub-district in Number (2017). Bogor (ID): Statistical Centre Board of Bogor Regency.

[SGC] Sukaputra Grahacemerlang (ID). (2017). Cityzen: Sentul City Free Magazine. Edition November 2017. Bogor (ID): PT Sentul City Tbk.

[UN] United Nations. (1979). Guidelines for Rural Centre Planning: Rural water supply and sanitation. New York

[UNESCO] United Nations of Educational, Scientific, and Cultural Organization. (2002). The UN Committee on Economic, Social and Cultural Rights adopted its general comment No. 15 on the right to water stating.

Walker, W.E., Loucks, D.P., Carr, G. (2015). Social Responses to Water Management Decisions. Environ. Process. (2015) 2:485509. DOI 10.1007/s40710-015-0083-5.

[WB] World Bank. (1993). The demand for water in rural areas: determinants and policy implications. World Bank Research Observer. 8(1): 47-70.

Yefni, Y., and Haris, M. (2019). Environmental Empowerment through CommunityBased Drinking Water and Sanitation (PAMSIMAS) Program Padang Mutung Kampar Village. Journal of Civil Society Vol 4, No 1 (2019).

Yusri, Y. (2019). Obstacles of Development of Empowerment of Human Resource in Village Fund (ADD) Budget Program in Tunjungan Village, District of Muara Kaman. Jurnal IImu Sosial, MAHAKAM Volume 8, Nomor 1, 2019: 50-68. 